\title{
PAPEL DO ENFERMEIRO NO APOIO EMOCIONAL E ORIENTAÇÃO DA FAMÍLIA DO POTENCIAL DOADOR DE ÓRGÃOS EM MORTE ENCEFÁLICA
}

\author{
Clesyane Alves Figueiredo \\ Especialista em Enfermagem pelo Centro Universitário Hermínio Ometto \\ clealvesfigueiredo@gmail.com
}

INTRODUÇÃO: Transplante de órgãos em geral é a única alternativa terapêutica para portadores de insuficiência funcional terminal. Existe desproporção entre o número de potenciais doadores versus o número de transplantes realizados. Cerca de $30 \%$ a $70 \%$ dos familiares discordam da prática de captação. O enfermeiro é fundamental na assistência ao potencial doador, pois o cuidado prestado engloba também a família. OBJETIVO: descrever, por meio de revisão integrativa, as condutas do enfermeiro ao orientar e dar apoio emocional à família sobre a morte encefálica e a possibilidade de doação de órgãos. MÉTODO: Revisão integrativa de literatura com busca na BIREME, LILACS, MEDLINE e SciELO no período de dezembro de 2017 a maio de 2018 por meio dos DeCs: família, enfermagem e transplantes de órgãos. Foram incluídos artigos, disponíveis em português, inglês e espanhol, publicados a partir do ano de 2013, e que abordassem a temática com aspectos da conduta do enfermeiro, orientações e apoio emocional frente à família do potencial doador de órgãos em morte encefálica. Após análise, considerando relevância científica e a correlação com o tema apresentado, fizeram parte da amostra 10 artigos, publicados entre 2013 a 2017. RESULTADO: Em 90\% da amostra, há relação do cuidado de enfermagem do paciente estendendo-o à família. Dos artigos, $40 \%$ demonstram que há evidência de uma assistência adequada, com esclarecimento sobre a doação de órgãos e o conceito de morte encefálica, desde suas primeiras etapas, e o enfermeiro se mostra fundamental para maior transparência e influencia de maneira positiva no modo como as famílias vão reagir frente a todo o processo. CONCLUSÃO: O enfermeiro é parte integrante de todas as etapas do processo de captação e transplante de órgãos, com papel fundamental. Além de orientar sobre as fases do processo de doação de órgãos, é essencial que o enfermeiro, por estar mais próximo da família, seja responsável pela humanização desse processo, acolhendo-a e ouvindo de maneira empática, e assim, estabelecendo uma relação de confiança com os familiares. 
Palavras-chave: Família. Enfermagem. Transplantes de órgãos. 